\title{
Remarks on Marenko (USSR) by Dewey (USA)
}

\author{
by THOM GEHRING \\ California State University, San Bernardino
}

Probably learning earlier about the work of Anton Makarenko from writer Maxim Gorky, philosopher and educator John Dewey went to visit the Soviet prison educator and prison reformer in 1928. Dewey believed "the Russians 'are more akin to the American people than to any other people" (Martin, J. [2002]. The Education of John Dewey: A Biography. New York: Columbia University Press, p. 356). Dewey went to the USSR in spite of official scrutiny of his motivations by the Federal Bureau of Investigation (Martin, 2002, p. 351). Dewey's visit was to one of Makarenko's schools, "a children's Colony. . .on the estate of a former Grand Duke" near Leningrad (Dykhuizen, G. [1973]. The life and mind of John Dewey. Carbondale: Southern Illinois University Press, p. 236).

... in Peterhof - up the Neva. . The place marks the nearest approach of the White [capitalist] armies to Leningrad [during the Civil War]; the buildings were more or less ruined in the warfare. . not yet wholly restored, since the teachers and children must do the work; there is still need in some quarters for hot water and whitewash. Two-thirds of the children are former 'wild children,' orphans, refugees, etc., taken from the streets. . .I have never seen. . .such a large proportion of intelligently occupied children. They were not lined up for inspection. We. . found them engaged in their various summer occupations, gardening, bee-keeping, repairing buildings, growing flowers in a conservatory (built and now managed by a group of particularly tough boys who began by destroying everything in sight), making simple tools and agricultural implements, etc. . . their manner and attitude is. . .what stays with me-I cannot convey it; I lack the necessary literary skill. But the net impression will always remain. If the children had come from the most advantageously situated families, the scene would have been a remarkable one, unprecedented. . When their almost unimaginable earlier history and background were taken into account, the effect was to leave me with. . .admiration for the capacities of the people from which they sprang. . . an unshakable belief in what they can accomplish. (Dewey, J. [1929]. Impressions of Soviet Russia and the Revolutionary World. New York: New Republic, Inc., pp. 27-29)

Makarenko operated this school under the auspices of the Soviet Police. Dewey was so impressed that in 1933 he helped make a film about Makarenko's educational ideas, which was titled after Makarenko's main book, The Road to Life (three vols). Dewey introduced the film with the following remarks:

Ten years ago, every traveler in Russia came back with stories of hordes of wild children who roamed the countryside and infested the streets. They were the orphans of soldiers killed in the war, of fathers and mothers who perished in the famine after the war. You will see a picture of their old road 
to life, a road of vagabondage, violence, thieving. You will also see their new road to. . .life, a road constructed by a brave band of Russian teachers. After methods of repression had failed, they gathered these children together in collective homes, they taught them cooperation, useful work, healthful recreation. Against great odds they succeeded. There are today no wild children in Russia. You will see a picture of great artistic beauty, of dramatic action and power. You will also see a record of a great historic episode. These boys are not professional actors. They were once wild children, they once lived in an actual collective. You will also see an educational lesson of the power of freedom, sympathy, work and play to redeem the juvenile delinquent; a lesson from which we too may learn (Dewey, in Bowen, J. [1965]. Soviet Education: Anton Makarenko and the Years of Experiment. Madison: University of Wisconsin, p. 4).

Thom Gehring is the research director of the Center for the Study of Correctional Education at California State University, San Bernardino. His scholarly emphasis is on the history of correctional education and prison reform. He has been a correctional educator since 1972. Thom did his Ph.D. dissertation on the correctional school district pattern of organization. He serves as the historian for the Correctional Education Association. Thom is a professor of education who directs the EDCA correctional and alternative masters degree program. 